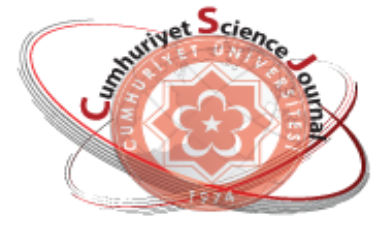

e-ISSN: $2587-246 X$

ISSN: $2587-2680$

\section{Cumburiyot Seionee Journal}

esg

Cumhuriyet Sci. J., Vol.40-1(2019)

\title{
Electrochemical Investigation of Carbon Nanotube Modified Surfaces Based on Ferricyanide and Guanine Signals for DNA Biosensor Applications
}

\author{
Dilşat ARIKSOYSAL \\ Ege University, Department of Analytical Chemistry, Faculty of Pharmacy, Izmir, TURKEY \\ Received: 12.07.2018; Accepted: 27.10.2019 \\ http://dx.doi.org/10.17776/csj.441382
}

\begin{abstract}
This study was designed to investigate the performance of carbon nanotubes (CNT) modified carbon paste and carbon printed electrodes (SPE) produced in laboratory conditions. The effect of carbon nanotube use on signal enrichment was determined by using cyclic voltammetry (CV), square wave voltammetry (SWV) or differential pulse voltammetry (DPV) techniques based on potassium ferricyanide/ ferrocyanide or guanine signal. The application of different activation procedures to the electrode surface such as chemical $\left(\mathrm{H}_{2} \mathrm{SO}_{4}\right.$, acetone, $\mathrm{N}, \mathrm{N}$-Dimethylformamide or $\left.\mathrm{NaOH}\right)$ or electrochemical (different potential applications) were presented in this study. It was observed that the activation procedure applied to the nanotube modified electrode has strong effects on signal enrichment. From these procedures it was determined that the guanine signal obtained in activation with $\mathrm{NaOH}$ increased about 62 -fold. It was also found that different nanotube species gave different responses to the activation processes. The optimum conditions of the nanotube-based biosensor were also presented.
\end{abstract}

Keywords: Electrochemical techniques, DNA, biosensor, carbon nanotubes, screen printed electrode(SPE), Nucleic Acid Hybridization.

\section{DNA Biyosensör Uygulamaları İçin Karbon Nanotüp Modifiye Yüzeylerin Ferrisiyanür ve Guanin Sinyallerine Dayalı Olarak Elektrokimyasal İncelenmesi}

\begin{abstract}
Özet. $\mathrm{Bu}$ çalışmada karbon nanotüpler (CNT) ile modifiye edilmiş karbon pastası (CPE) ve laboratuvar koşullarında basılarak üretilen perde baskılı karbon (SPE) elektrotların performansı karşılaştırılmış ve dönüşümlü voltametri(CV), kare dalga voltametri (SWV) veya diferansiyel puls voltametri (DPV) teknikleri kullanılarak elde edilen potasyum ferri / ferrosiyanür veya guanin sinyallerindeki artış miktarı tayin edilmiştir. $\mathrm{Bu}$ çalışmada elektrotlara kimyasal $\left(\mathrm{H}_{2} \mathrm{SO}_{4}\right.$, aseton, $\mathrm{N}$, N-Dimetilformamid veya $\left.\mathrm{NaOH}\right)$ veya elektrokimyasal (farklı potansiyel uygulamaları) gibi farklı aktivasyon prosedürleri uygulanmıştır. Nanotüp modifiye elektrota uygulanan aktivasyon prosedürünün sinyal zenginleşmesi üzerine güçlü etkileri olduğu gözlenmiştir. Bu prosedürlerden $\mathrm{NaOH}$ ile aktivasyonda elde edilen guanin sinyalinin yaklaşık 62 kat arttığ tespit edilmiştir. Bu çalışmada ayrıca farklı nanotüp türlerinin aktivasyon proseslerine farklı yanıtlar verdiği de bulunmuştur. Nanotüp bazlı biyosensörün optimum şartları da ayrıca sunulmuştur.
\end{abstract}

Anahtar Kelimeler: Elektrokimyasal teknikler, DNA, biyosensör, karbon nanotüpler, perde baskılı elektrot (SPE), Nükleik asit hibridizasyonu.

\footnotetext{
* Corresponding author. Email address: dilsat.ariksoysal@ege.edu.tr

http://dergipark.gov.tr/csj C2016 Faculty of Science, Sivas Cumhuriyet University
} 


\section{INTRODUCTION}

New generation DNA biosensor systems, including simple, precise, fast and easy-to-use methods, continue to be developed for routine medical applications such as genetic diagnosis along with the advancements in nanotechnology. These bio-devices designed for the specification of many genetic disorders include various nanomaterial-based assay methodologies. Among them electrochemical DNA biosensors, which were developed as an alternative to classical test methods and other biosensor systems, have some powerful benefits such as the monitoring of signals are more rapid and direct [1] than other i.e. optical or piezoelectric biosensor systems. However, in all cases, DNA detection with these nanosystems is usually based on signal enrichment. In fact, the aim of using nanomaterials in biosensor systems is to provide more biomaterial binding to the sensor surface. In this case, when the signal is enhanced, the limit of detection can be reduced considerably. Carbon nanotube(CNT) contained electrochemical biosensors have still received considerable interest from researchers because of their rapid electron transport and high biomolecule binding capacity via self-assemble strategies [2-6]. They have been used for many of detection purposes up to now such as drug-DNA interactions [7, 8], DNA hybridization sensing $[9,10]$, biomolecular interactions by hybrid assemblies [11-13] etc.

Hexagonal graphitic sheets-based CNTs are divided into two groups as single-walled carbon nanotubes (SWCNT) and multi-walled carbon nanotubes (MWCNT). They both have a very high surface area with nanometers range and their lengths can be micron levels. CNTs have still been used for preparation of a sensitive sensing layers in the field of biosensor design technologies due to amplifying recognition events. However, in order to increase the sensing signal, it is necessary to find some optimum conditions. Because the amount of signal increase, arising from the nanomaterial is influenced by experimental conditions as well as nanomaterial characteristics. For example, SWCNTs-modified electrode gave lover detection limit than
MWCNTs modified one for the amperometric determination of hydrogen peroxide and phenolic compounds that was reported by Chekin et al. [14] Another example was presented by Erdem et al. related to CNTs-based biosensor design for the detection of Microcystis spp gene sequences. In their work, higher oxidation signals of guanine and adenine were obtained using MWCNTsmodified screen printed electrode in comparison to the SWCNTs-contained one[15]. Jeong et al. was developed the thrombin sensor by using bare(unmodified), gold nano particle (GNP), SWCNT or MWCNT modified electrodes in order to investigate the surface effect on SWV signals in that work [16].

On the other hand, in electrode systems carrying microchip substructure such as screen printed or pencil graphite electrodes, polymers are used in both commercial and hand-made electrodes to hold the powdery materials (i.e. gold particles, graphite, carbon nanotubes, etc.) together and to adhere them to the solid surface. This causes decrease in electron transfer kinetics and thus low signal acquisition from sensor surfaces. In electrochemical studies, application of the activation process to the electrode surface is very important in order to obtain reproducible results. The activation of the aforementioned disposable, nanomaterial-containing electrodes prior to use is also important for obtaining both reproducible and enriched signals. In addition, pretreatment of the electrodes helps to form - $\mathrm{COOH}$ groups on the SPE surface which increase the hydrophilicity of the surface and its reproducibility, thereby remove possible contaminants from the sensor [17]. In other words, there is an increment for active sites on the working electrode.

In this study, suitable experimental conditions for the use of nanotube modified electrodes in biosensor systems were investigated. It is aimed to obtain the highest electrochemical response with handmade carbon paste (CPE) and screen printed carbon electrode (SPE) containing bamboo or hollow type carbon nanotubes. As known, it is very important in electrochemical biosensor systems to reduce the detection limit of the sensor 
depending on the level of the signal obtained because of biochemical interaction. Here, the contribution of the nanomaterial to reducing the detection limit of the biosensor (or contribution to enhancing the signal obtained from the sensor) was explored using different experimental conditions. Basically, the disposable electrodes were prepared in the laboratory using a screen printed electrode machine to contain certain percentages of nanotubes firstly. Electrodes were then chemically or electrochemically activated by chemical treatment or applying positive potential onto the surface of the working electrodes in order to increase sensitivity and stability of the device. Electrochemical responses of potassium feri/ferrocyanide or guanine were measured and evaluated based on cyclic, square wave or differential puls voltammetry techniques. To our knowledge, optimum parameters (or operating conditions) of nanomaterial modified electrodes should be determined before the biosensor designs so that the developed biosensors can have features such as low detection limit, rapid analysis capability which are requirements of medical DNA tests. Advantages and disadvantages of these electrodes were evaluated in the following sections.

\section{MATERIAL AND METHODS}

\subsection{Apparatus, Chemicals and Sample Preparation}

AUTOLAB 12 potatiostat/galvanostat device (Eco Chemie, Netherlands) containing the software package GPES 4.9 (General Purpose Electrochemical System) was used for electrochemical measurements. Savitzky and Golay filter (level 2) of the software was preferred to smooth raw DPV voltammograms.

Disposable screen-printed electrodes (SPE) were prepared in the Firenze University, biosensor laboratory, Florence, Italy. They consisted of a silver (pseudo) reference electrode, a graphite working electrode $(\varnothing=3 \mathrm{~mm})$ and a graphite auxiliary electrode as similarly reported in Carpini et al. [18] (Scheme 1). The carbon SPEs were printed by using a screen-printer machine (Model 248, DEK, Weimouth, UK). A Electrodag 423 SS model graphite ink and a Electrodag $410 \mathrm{PF}$ model silver ink purchased from Acheson (Milan, Italy), a Vinyl fast 36-100 model insulating ink was obtained from Argon, Lodi, (Milan, Italy). An Autostat CT5 type polyester film purchased from Autotype (Milan, Italy) for the printing substrate. The silver ink was also used to serve as the conductive tracks. The thin sheet was fixed to the polycarbonate support so that the desired electrode thickness could be obtained. The SPE connector was used as the interface in all measurements.

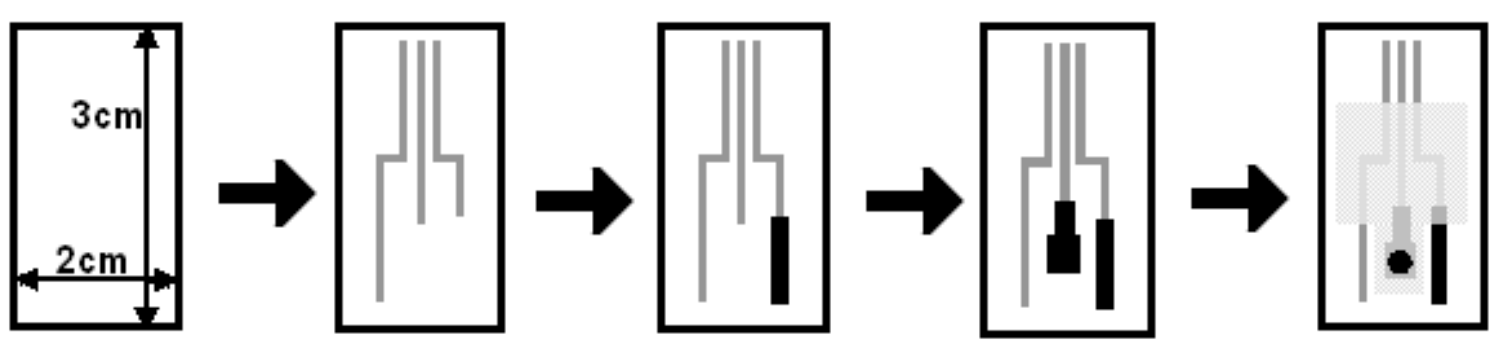

Scheme $1.2 \mathrm{~cm}$ wide and $3 \mathrm{~cm}$ long electrode printing process contains printing of silver ink for pseudo-reference electrode and electrical contact layers (a), printing of counter(b) and working(c) electrodes by using carbon ink, and printing of insulating layer(d) by using the insulating ink respectively. Carbon ink of the working electrode contained $1 \%, 2 \%$ or $5 \%$ ratio of carbon nanotubes.

Graphite powder and all types of CNTs (SWCNTs, hollow/bamboo structure of MWCNTs) purchased from Sigma-Aldrich.
The other three electrode system used in this study consisted of the surface-renewable carbon paste electrode (CPE) as the working electrode, a 
reference electrode $(\mathrm{Ag} / \mathrm{AgCl})$, and a counter electrode (platinum wire). A $3 \mathrm{~mm}$ i.d. of glass tube was used as the body of the CPE and the mixture of carbon paste was packed in it. The electrical conductivity was provided using copper wire passed through the paste-filled tube. Carbon paste mixture composed of graphite powder (Fisher) and mineral oil (Acheson 38) in a 70:30 mass ratio. The CPE surface was polished by using a weighing paper before use.

\subsection{Synthetic DNA materials}

Double-stranded (ds) calf thymus DNA was purchased from Sigma-Aldrich (Milan, Italy). The stock solution of dsDNA $(1000 \mu \mathrm{g} / \mathrm{ml})$ was prepared with Tris-EDTA buffer (10mM Tris$\mathrm{HCl}, 1 \mathrm{mM}$ EDTA, $\mathrm{pH} 8.00$ ) and store at freezer. More diluted solutions of DNA were prepared with $0.50 \mathrm{M}$ acetate buffer ( $\mathrm{pH} 4.80$ ) (ABS).

\subsection{Chemicals}

Sodium dihydrogen phosphate, disodium hydrogen phosphate, and acetic acid were obtained from Sigma (Milan, Italy). All reagents were of analytical grade and ultrapure water $(18 \Omega)$ was used in all preparations of solutions (Elgastat, England). All experiments were carried out at room temperature provided by air condition $\left(22.0-25.0^{\circ} \mathrm{C}\right)$.

\subsection{Methods}

Scheme 2 shows the experimental details of the CNT-based biosensor. In the first part of the study, a $20 \mu \mathrm{g} / \mathrm{ml}$ fish sperm double stranded DNA(dsDNA) was immobilized to various percentages such as $1 \%, 2 \%, 5 \%$ of SWCNTcontaining CPE electrode. The increase in guanine oxidation signal was monitored by square wave and compared to the bare electrode. Guanine, which is an electroactive DNA base, is oxidized at about $+1.0 \mathrm{~V}$ potential at acetate buffer ( $\mathrm{pH}: 4.80)$ medium. In the second part, $20 \mu \mathrm{g} / \mathrm{ml}$ dsDNA was attached to the surface of the SPEs that had been printed to contain SWCNTs/MWCNTs and the resulting of the electron transfer in the Nernst difussion layer was measured based on potassium ferri/ferrocyanide by cyclic voltammetry or guanine signal by differential pulse voltammetry. CNT-related signal enhancement was observed at different pretreatment conditions.

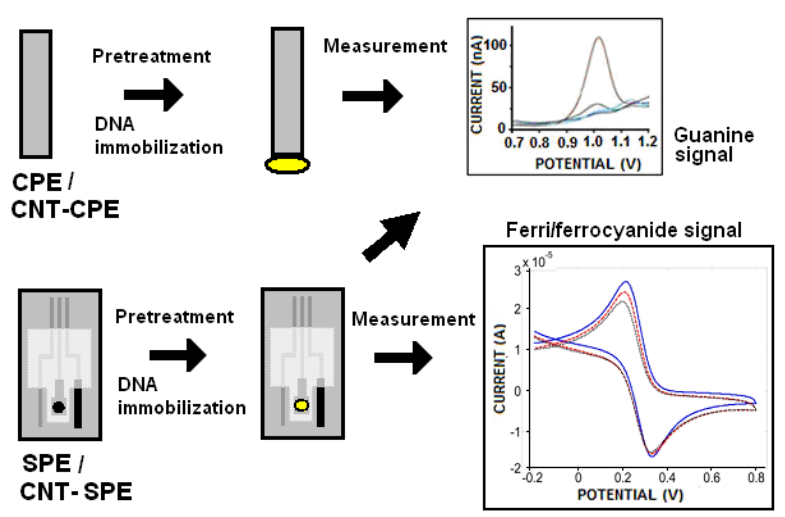

Scheme 2. Schematic diagrams illustrating the experimental steps of bare/CNTs-modified CPE and SPE electrodes and the detection of CNT-related signal enhancement based on guanine or ferri/ferrocyanide signals.

\subsubsection{The preparation of sensor surfaces.}

The pretreatment of SWCNTs-modified CPE was made by applying a potential of $+1.70 \mathrm{~V}$ vs. reference electrode for $20 \mathrm{~s}$ or $0 \mathrm{~V}$ (open circuit potential) for 20sec. in acetate buffer solution (0.50 M ABS; pH 4.80) without stirring. The $20 \mu \mathrm{g} / \mathrm{mL}$ of dsDNA prepared in ABS was subsequently modified onto the activated surface of CPE by applying a fixed potential of $+0.20 \mathrm{~V}$ for $5 \mathrm{~min}$. The dsDNA immobilized CPE was then rinsed with $\mathrm{ABS}$ twice.

On the other hand, a $100 \mu \mathrm{L}$ of ABS droplet was put on SWCNTs-contained SPEs for the pretreatment of their carbon working electrode surfaces. The different pretreatment and DNA immobilization conditions are as follows:

Table 1. The table showing the electrochemical activation processes applied in biosensor experiments with screen printed carbon electrode for guanine signal measurements.

\begin{tabular}{ll}
\hline $\begin{array}{l}\text { Pretreatment } \\
\text { (in ABS) }\end{array}$ & DNA immobilization \\
\hline $1.2 \mathrm{~V}$ for $60 \mathrm{~s}$. & Passive adsorption for 2min. \\
\hline $1.6 \mathrm{~V}$ for $60 \mathrm{~s}$. & Passive adsorption for $2 \mathrm{~min}$. \\
\hline $1.8 \mathrm{~V}$ for $60 \mathrm{~s}$. & Passive adsorption for $2 \mathrm{~min}$. \\
\hline $\begin{array}{l}1.6 \mathrm{~V}, 120 \mathrm{~s} .+1.8 \mathrm{~V}, 60 \\
\text { s. }\end{array}$ & Passive adsorption for $2 \mathrm{~min}$. \\
\hline $2.0 \mathrm{~V}$ for $60 \mathrm{~s}$. & Passive adsorption for 2min. \\
\hline $1.8 \mathrm{~V}$ for $60 \mathrm{~s}$. & $\begin{array}{l}+0.50 \mathrm{~V} \text { for } 120 \mathrm{~s} . \text { with stirring } \\
(200 \mathrm{rpm} .)\end{array}$ \\
\hline
\end{tabular}


After pretreatment SPEs were then rinsed with $100 \mu \mathrm{L}$ of blank ABS two times using micropipette. Each electrode strip was covered with a droplet including $20 \mu \mathrm{g} / \mathrm{ml}$ of dsDNA in ABS. After 2 min. of DNA immobilization under open circuit potential application $(\sim 0 \mathrm{~V})$, they were washed with the same buffer for 30s. with 200 rpm stirring. The electrodes were then coated with $100 \mu \mathrm{L}$ of new drop of ABS so that their surfaces were not dry, and were left to stand until measurement.

\subsubsection{Different pretreatment applications}

Various activation techniques were applied to MWCNTs-modified SPEs (carbon ink contained $2 \%$ ratio of hollow or bamboo structure of MWCNTs) to achieve optimal signal enrichment. For example;

i. $\mathrm{H}_{2} \mathrm{SO}_{4}$ pretreatment: $2 \mathrm{CV}$ scans (from -1.0 to $+1.0 \mathrm{~V}$ ) in $0.2 \mathrm{M} \mathrm{H}_{2} \mathrm{SO}_{4}$

ii. Acetone pretreatment: $10 \mu \mathrm{L}$ drop (acetone/water 1:1) on the working electrode surface for $10 \mathrm{~min}$.

iii. N,N-Dimethylformamide pretreatment: 10 $\mu \mathrm{L}$ drop on the surface till dryness.

iv. $\mathrm{NaOH}$ pretreatment: $+1.5 \mathrm{~V}$ for $2 \mathrm{~min}$ in $1 \mathrm{M}$ $\mathrm{NaOH}$.

\subsubsection{Electrochemical Measurements}

The electrochemical transduction of the oxidation and reduction peaks of $\mathrm{Fe}(\mathrm{CN})_{6}^{3-/ 4-}$ were recorded with cyclic voltammetry $(\mathrm{CV})$ technique scanning from $-0.25 \mathrm{~V}$ to $+0.65 \mathrm{~V}$ potential range, $50 \mathrm{mV}$ scan rate and $3 \mathrm{mV}$ step potential. The oxidation signal of guanine was measured directly by square wave voltammetry scanning from +0.20 to $+1.35 \mathrm{~V}$ potential range versus $\mathrm{Ag} / \mathrm{AgCl}$ reference electrode (or Ag-Pseudo-reference electrode) in the $\mathrm{ABS}$ aliquot at $40 \mathrm{mV}$ pulse amplitude, $15 \mathrm{mV}$ step potential and $200 \mathrm{~Hz}$ frequency. The oxidation signal of guanine was also measured in blank ABS by DPV by scanning from +0.70 to $+1.45 \mathrm{~V}$ with the amplitude of $50 \mathrm{mV}$ at $16 \mathrm{mV} / \mathrm{s}$ scan rate. If necessary, the raw curve was treated by using the software program of GPES "Savitzky and Golay fitler" (level 2) with moving average baseline correction, using a "peak width" of 0.01 V.

Each procedure explained above was repeated at least three times and repetitive measurements were performed by refreshing the surface by using both electrochemical transducers.

\section{RESULTS AND DISCUSSION}

In theese studies, increased $\mathrm{Fe}(\mathrm{CN})_{6}^{3-/ 4-}$ or guanine signals in the presence of CNTs were evaluated.

\subsection{DNA detection based on guanine signal by using SWCNTs-modified CPE}

First, the effect of the pretreatment applied to CPE surface on guanine signals was investigated and the results are shown in Figure 1. The peak currents of the guanine signal obtained from the unpretreated and pretreated electrodes by SWV technique are shown below. The oxidation of the guanine was obtained at about $+1.00 \mathrm{~V}$ in the absence and presence of SWCNTs modification.

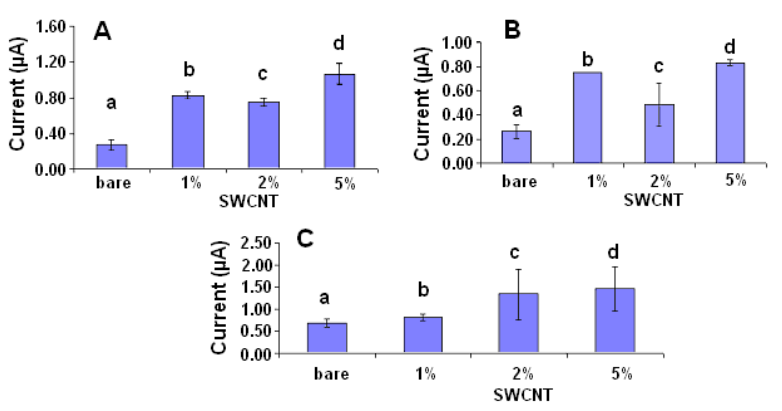

Figure 1. Graphs show the magnitude of guanine oxidation signals obtained from dsDNA immobilized surfaces (A) unpretreated $\mathrm{CPE}$, (B) only 20s. ABS pretreated CPE (without potential application) (C) pretreated CPE applying at $+1.7 \mathrm{~V}$ potential during $20 \mathrm{sec}$. and each column presents (a) bare electrode in the absence of carbon nanotube, (b) CNTcontained electrode in the presence of $1 \%$ SWCNTs, (c) $2 \%$ of SWCNTs and (d) $5 \%$ of SWCNTs modification onto CPEs.

The magnitude of guanine peak observed with dsDNA modified unpreated (Figure 1A, a) and ABS pretreated (Figure 1B, a) CPEs in the absence of CNTs were about the same (main averege responses $\sim 0.30 \mu \mathrm{A}$ ). However, the electrochemically pretreated CPE (Figure 1C, a) gave the highest signal after dsDNA immobilization onto the CNTs-free electrode 
surface. All of these results indicated that the activation process with potential application $(+1.70 \mathrm{~V}$ during $20 \mathrm{sec}$.) enhances DNA binding onto the sensor surface.

On the other hand, guanine signal obtained from dsDNA modified SWCNTs electrodes were higher (Figure 1A; b,c and d, Figure 1B; b, c and d) than that obtained CNTs-free electrode (Figure 1A, a and Figure 1B, a) in the absence of potential application for pretreatment. When these increased signals are evaluated, it is seen that the electrode with different ratios of CNT has approximately 3-4 times more response than CNTs-free electrode (Figure 1A; b,c and d, Figure $1 \mathrm{~B} ; \mathrm{b}, \mathrm{c}$ and $\mathrm{d})$. The highest guanine signal was obtained with 5\% SWCNTs modified unpretreated electrode (Figure 1A; c). But when the pretreatment process is applied to the CNTscontained electrode surface, only two fold signal enhancement was obtained from CPE with $2 \%$ and 5\% SWCNTs without reproducibility.

A series of three repetitive DPV measurements of the guanine signal at $20 \mu \mathrm{g} / \mathrm{ml}$ concentration level of fish-sperm dsDNA modified unpretreated electrode with 5\% SWCNTs resulted in reproducible results such as a mean response about $1.10 \mu \mathrm{A}$ with a relative standard deviation of $9.8 \%$ was calculated. As unsatisfactory and nonreproducible responses were obtained with DNA modified CPE, further studies were continued with SPE.

\subsection{SWCNT-based studies by using SPE}
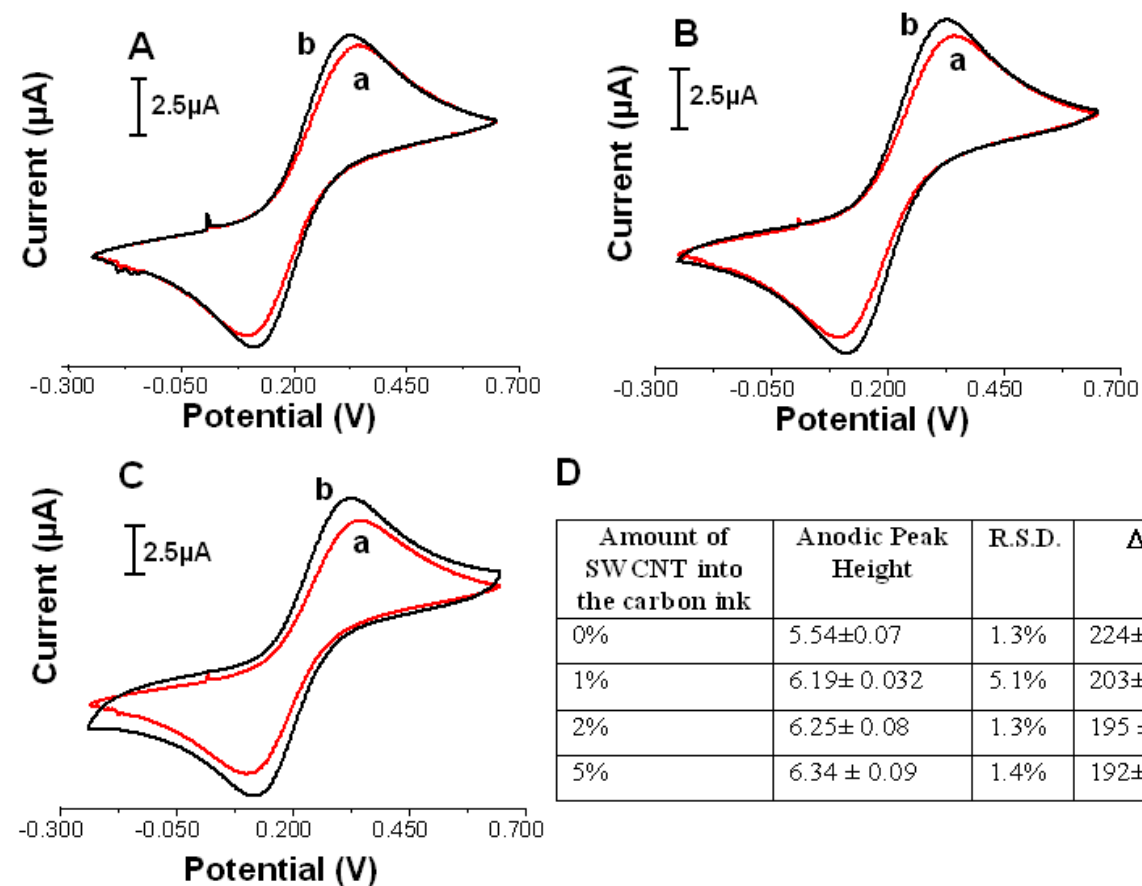

D

\begin{tabular}{|l|l|l|l|l|}
\hline $\begin{array}{c}\text { Amount of } \\
\text { SW CNT into } \\
\text { the carbon ink }\end{array}$ & $\begin{array}{c}\text { Anodic Peak } \\
\text { Height }\end{array}$ & R.S.D. & \multicolumn{1}{|c|}{$\Delta$ EP } & R.S.D. \\
\hline $0 \%$ & $5.54 \pm 0.07$ & $1.3 \%$ & $224 \pm 2.89$ & $1.3 \%$ \\
\hline $1 \%$ & $6.19 \pm 0.032$ & $5.1 \%$ & $203 \pm 18.73$ & $9.2 \%$ \\
\hline $2 \%$ & $6.25 \pm 0.08$ & $1.3 \%$ & $195 \pm 2.52$ & $1.3 \%$ \\
\hline $5 \%$ & $6.34 \pm 0.09$ & $1.4 \%$ & $192 \pm 1.73$ & $0.9 \%$ \\
\hline
\end{tabular}

Figure 2. Cyclic voltammogram of $10 \mathrm{mM} \mathrm{K} 4\left[\mathrm{Fe}(\mathrm{CN})_{6}\right] / \mathrm{K}_{3}\left[\mathrm{Fe}(\mathrm{CN})_{6}\right](1: 1)$ containing $1 \mathrm{M} \mathrm{KCl}$ obtained from unpretreated bare (a) and SWCNTs-modified (b) SPE surfaces. The modification rates of SWCNTs in SPE are 1\%(A), 2\% (B) and 5\%(C), respectively. The comparison of the electron transfer features of modified SPEs was also showed in the inset Table (D).

SWCNTs were simply mixed into the carbon ink of the SPE transducer with different rates as $1 \%$, $2 \%$ and $5 \%$ as explained in the experimental part, and the electron transfer rate of modified electrodes was monitored using CV as shown in
Figure 2. The differentiations in $\mathrm{CV}$ measurements were showed between the CNTsfree and CNTs-modified SPEs. According to the results, CNTs-contained electrode gave higher signal than bare electrode in each modification 
conditions and the height of the anodic peak showed negative shift (approximately $21 \mathrm{mV}(1 \%)$, $29 \mathrm{mV}(2 \%)$ and $32 \mathrm{mV}(5 \%)$ respectively) in the Epa of $\mathrm{Fe}(\mathrm{CN}) 63 \% 4^{-}$(Figure 2A, B and C). Figure 2D also presents anodic peak heights and $\Delta E p$ values of bare and modified electrodes with relative standard deviation values. The results indicated that the SWCNTs modified electrodes provide enhanced electron transfer rate (Figure $2 \mathrm{~A}, \mathrm{~B}$ and C; approximately $11.7 \%, 12.8 \%$ and
$14.4 \%$ of signal enhancement respectively) in comparison to the bare electrode. This result can be explained by carbon nanotube modified surfaces have better conductivity than simple carbon surfaces.

The effect of SWCNTs modification on intrinsic guanine response in different electrochemical pretreatment conditions by using SPE was showed in Figure 3.
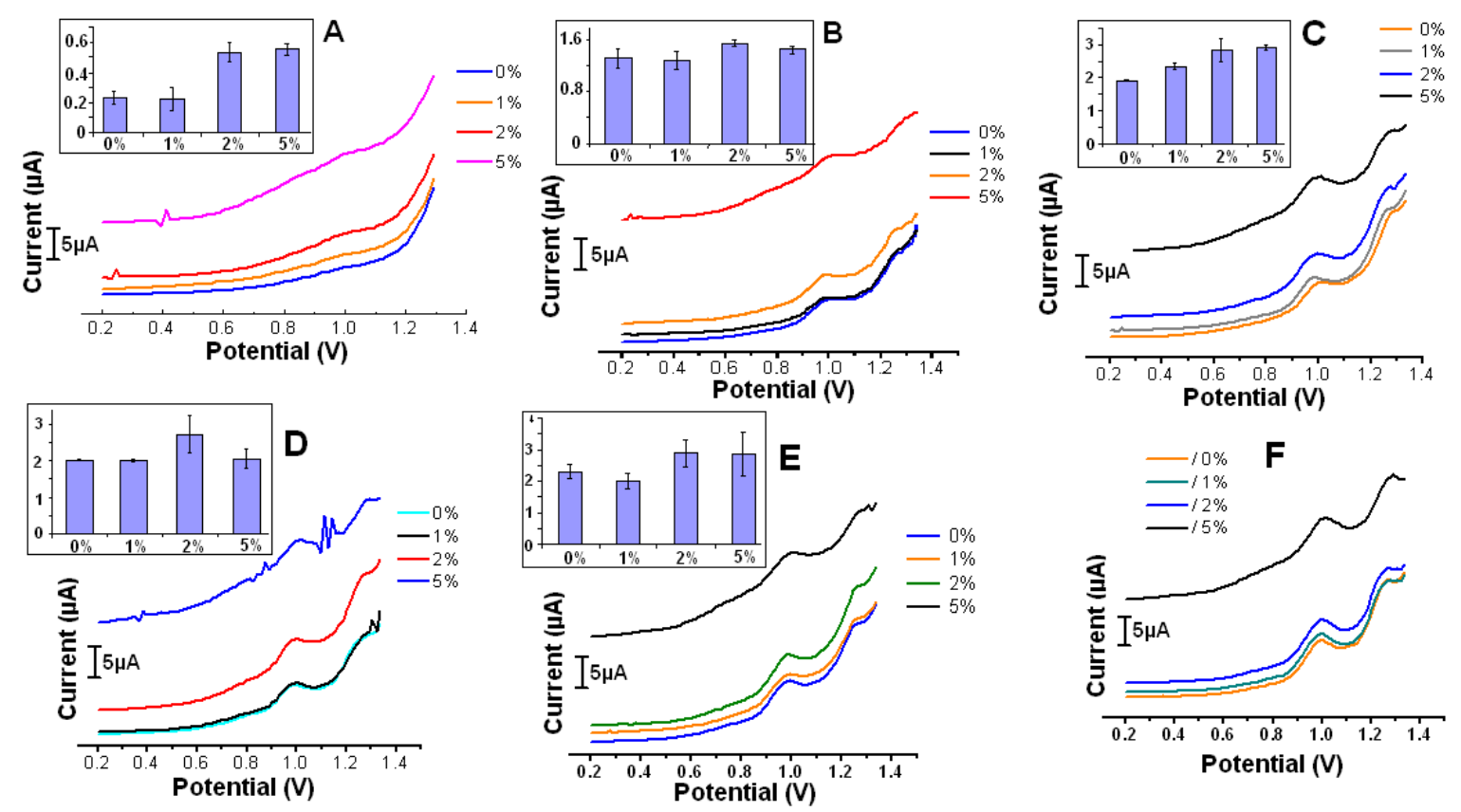

Figure 3. Voltammetric signal of guanine related to dsDNA modified sensor obtained by different pretreatment conditions such as (A) $1.2 \mathrm{~V}$ for $60 \mathrm{~s}$;; (B) $1.6 \mathrm{~V}$ for $60 \mathrm{~s}$; (C) $1.8 \mathrm{~V}$ for $60 \mathrm{~s}$; (D) $1.6 \mathrm{~V}, 120 \mathrm{~s}$. and $1.8 \mathrm{~V}, 60 \mathrm{~s}$. together; (E) $2.0 \mathrm{~V}$ for $60 \mathrm{~s}$.; (F) $1.8 \mathrm{~V}, 60 \mathrm{~s}$. respectively. dsDNA concentration was used as $20 \mu \mathrm{g} / \mathrm{mL}$ and it was immobilized onto the surface of SPE by passive adsorption for $2 \mathrm{~min}$. (A, B, C, D, and E) or potential application $(+0.50 \mathrm{~V}$ for 120sec. with 200rpm. stirring, F). SWV parameters were described in the experimental section and Table 1.

The first thing to notice when looking at all the raw results obtained from figure $3 \mathrm{~A}, \mathrm{~B}, \mathrm{C}, \mathrm{D}, \mathrm{E}$ and $\mathrm{F}$ is that the baseline of $5 \%$ modification is higher than unmodified $(0 \%)$ and other rate of CNTs modifications ( $1 \%$ or $2 \%)$. Another point is that the peaks obtained from the $+1.2 \mathrm{~V}$ potential applied electrodes for the pretreatment (Figure $3 \mathrm{~A}, 0 \%, 1 \%, 2 \%, 5 \%)$ are much lower than the other electrochemically pretreated electrodes. (Figures 3B, C, D, E and F). However, the signal difference between bare and CNT-coated electrodes activated by applying the $+1.2 \mathrm{~V}$ potential (Figure $3 \mathrm{~A}$ ) is grater than more positive potential applied SPEs (Figure 3B, C, D, E and F).
In Figure 3A, it is seen that approximately $0.23 \mu \mathrm{A}$ of guanine signals were obtained with both the unmodified $(0 \%)$ and the modified electrode with $1 \%$ CNT. However, in the presence of $2 \%$ or $5 \%$ of CNTs modification onto SPE, about 2.4 times higher guanine signal (average response $\sim 0.55 \mu \mathrm{A}$ ) was measured in comparison to the unmodified or $1 \%$ ratio of CNTs modified sensor. The relative standard deviation (RSD) of three repetitive measurements was calculated as $10 \%$ in the presence of $2 \%$ CNTs modification and $7 \%$ in the presence of 5\% CNTs modification onto the SPE. Acording to the Figure $3 \mathrm{~A}$, it is proved that more sensitive DNA analysis was achieved by using 
CNTs-modified $(2 \%$ or $5 \%)$ screen printed electrodes.

On the other hand, the expected increase at guanine signal could not be achieved with $1.6 \mathrm{~V}$ potential applied CNT-contained electrodes (Figure 3B). In figure 3C, when compared the detection performance of modified electrodes with unmodified electrodes, it was observed that there was an approximately 1.5 -fold increase in the presence of CNT (2\% and 5\% ratios). However, the reproducibility of the results was not good especially for $2 \%$ of CNTs modified transducer.
When the pretreatment potential or time is further increased (Figure 3D and E) or if DNA immobilization is carried out under potential application (Figure 3F), it was observed that the CNTs modified and unmodified electrodes gave similar guanine responses (The average peak potential of all electrodes was obtained as 3$3.5 \mu \mathrm{A})$. In other words, the signal increase expected with the modified electrodes could not be observed. This situation did not change with the extension of the DNA immobilization time (data not shown).

\subsection{MWCNTs-based studies by using SPE.}
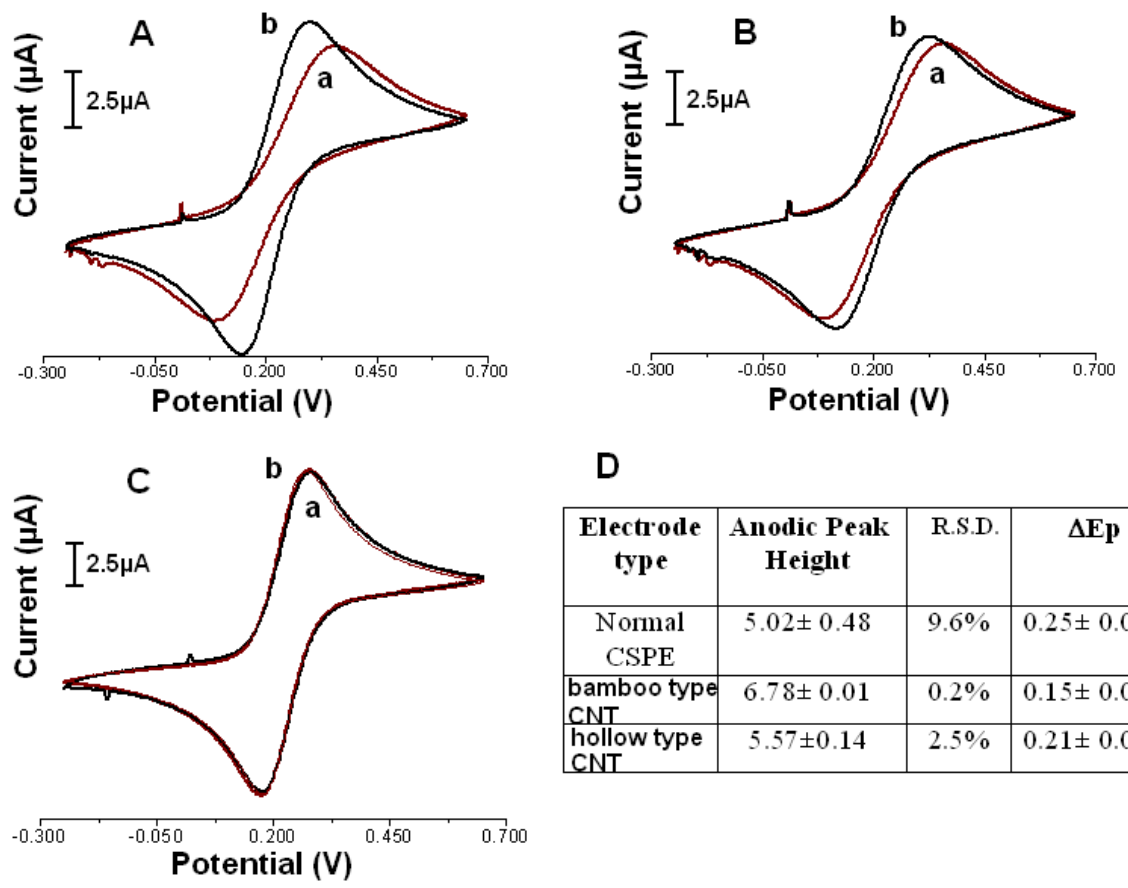

D

\begin{tabular}{|c|c|c|c|c|}
\hline $\begin{array}{c}\text { Electrode } \\
\text { type }\end{array}$ & $\begin{array}{c}\text { Anodic Peak } \\
\text { Height }\end{array}$ & R.S.D. & $\Delta$ Ep & R.S.D. \\
\hline $\begin{array}{c}\text { Normal } \\
\text { CSPE }\end{array}$ & $5.02 \pm 0.48$ & $9.6 \%$ & $0.25 \pm 0.023$ & $9.2 \%$ \\
\hline $\begin{array}{l}\text { bamboo type } \\
\text { CNT }\end{array}$ & $6.78 \pm 0.01$ & $0.2 \%$ & $0.15 \pm 0.002$ & $1.3 \%$ \\
$\begin{array}{l}\text { hollow type } \\
\text { CNT }\end{array}$ & $5.57 \pm 0.14$ & $2.5 \%$ & $0.21 \pm 0.004$ & $2.5 \%$ \\
\hline
\end{tabular}

Figure 4. Voltammograms obtained from bare (a) and MWCNTs-modified (b) SPE surfaces with the solution of $10 \mathrm{mM}$ $\mathrm{K}_{4}\left[\mathrm{Fe}(\mathrm{CN})_{6}\right] / \mathrm{K}_{3}\left[\mathrm{Fe}(\mathrm{CN})_{6}\right](1: 1)$ containing $1 \mathrm{M} \mathrm{KCl}$. The modifications of $2 \%$ ratio of MWCNTs in SPE are bamboo structure (A and C), hollow structure (B) and the surface of the SPEs were unpretreated (A and B) or pretreated (C). CV measurement parameters as explained in Figure 2. The comparison of the electron transfer features of modified SPEs was also showed in the inset Table (D).

As explained in the experimental part, MWCNTs were simply mixed into the carbon ink of the SPE transducer with $2 \%$ ratio (In the direction of the previously obtained results from DNA-based studies, $2 \%$ CNT modification was performed on the electrodes.). Differentiations in $\mathrm{CV}$ measurements performed in $\mathrm{Fe}(\mathrm{CN})_{6}^{3-/ 4-}$ solution were presented in Figure 4. In this experiment, CNTs-free and different types of MWCNTsmodified SPEs were used to to measure the effect of CNT modification on conductivity. Figure 4A and $4 \mathrm{C}$ show the responses obtained from bamboo-type MWCNTs modified SPE and Figure 4B presents the CV of hollow-type CNTcontained electrode. Red lines of each figure show the response of unmodified (CNTs-free) electrode. The most increase at the signals of ferri/ferro cyanide ( 3.2 folds) was obtained with bamboostructure MWCNTs modified and unpretreated SPE (Figure 4A, black line), in contrast to to the 
signals observed using hollow-structure CNT modified (Figure 4C, black line) and pretreated bamboo-type CNT-modified SPEs (black line of Figure 4B). The electrochemical pretreatment $(1.6 \mathrm{~V}$ for $2 \mathrm{~min}$ and $1.8 \mathrm{~V}$ for $1 \mathrm{~min}$ in acetate buffer) protocol for SPE destroyed the signal enhancement obtained by bamboo-type MWCNT modification (Figure 4C, black line). Since pretreatment was required for electrode surface optimization, it was decided to apply different pretreatment procedures in subsequent experiments. When all the results obtained using 2\% bamboo-type MWCNT-modified SPEs were evaluated (Figure 4A and D), it was observed that these electrodes gave about $35 \%$ more $\mathrm{Fe}(\mathrm{CN}) 6^{3-/ 4-}$ signal than the bare electrode(Figure 4A, black line) and $22 \%$ more than the SPE containing SWCNT(Figure 2B and D) under the same experimental conditions.

On the other hand, if hollow-type MWCNT(Figure 4B and D) is used for the modification of SPE, only $11 \%$ increase in signal was observed compared to bare electrode. Thus, the high level increment at $\mathrm{Fe}(\mathrm{CN})_{6}^{3-14-}$ signal (Figure 4A) indicate that bamboo-type MWCNTs can provide enhanced electron transfer rate and higher surface area on the SPE. The comparison of the electron transfer features of modified SPEs based on $\Delta \mathrm{Ep}$ values were also showed in the Table (D).

\section{Different pretreatment conditions}

Different pretreatment procedures were applied [19-22] to the sensor surface to obtain the highest and reproducible responses from the CNT modified electrode. All these procedures were used for the analysis of different target molecules such as organophosphates [22].

Figure 5 shows the average signals of ferri/ferrocyanide obtained after the different pretreatment applications on MWCNT-contained SPE surface such as (A and B) $\mathrm{H}_{2} \mathrm{SO}_{4}$ pretreatment: $2 \mathrm{CV}$ scans (from -1.0 to $+1.0 \mathrm{~V}$ ) in $0.2 \mathrm{M} \mathrm{H}_{2} \mathrm{SO}_{4}$ for bamboo type $\mathrm{CNT}(\mathrm{A})$ and hollow-type CNT(B) modified electrodes; (C and D) Acetone pretreatment: $10 \mu \mathrm{L}$ drop (acetone/water 1:1) on the working electrode surface for $10 \mathrm{~min}$. for bamboo type CNT(C) and hollow-type CNT(D) modified electrodes; (E) N,N-Dimethylformamide pretreatment: $10 \mu \mathrm{L}$ drop on the surface till dryness for bamboo-type CNT modified electrode; (F) $\mathrm{NaOH}$ pretreatment: $+1.5 \mathrm{~V}$ for $2 \mathrm{~min}$ in $1 \mathrm{M} \mathrm{NaOH}$ for bamboo-type CNT modified electrode respectively. CV parameters were described in the experimental section and Figure 2.

According to the Figure 5, when $\mathrm{NaOH}(1 \mathrm{M})$ pretreatment was applied to the SPE by using $+1.5 \mathrm{~V}$ potential for $2 \mathrm{~min}$. or diluted acetone solution (1:1) was used for pretreatment of the SPE for $10 \mathrm{~min}$ duration better results were obtained with them when compared to the $\mathrm{H}_{2} \mathrm{SO}_{4}$ or dimethyl formamide activated electrode surfaces based on ferri/ferrocyanide signal.

The signal increment ratio about $70 \%$ was found to be the best result obtained with the acetone pretreated and bamboo-structure CNT modified SPE (Figure 5C). However, with other $\mathrm{H}_{2} \mathrm{SO}_{4}$ (Figure $5 \mathrm{~A}$ ) and $\mathrm{NaOH}$ (Figure $5 \mathrm{~F}$ ) pretreatment conditions, a signal increase of about $30 \%$ was obtained with the bamboo-structure CNT modified electrode.

On the other hand, no sufficient increase in DNA signals could be obtained with pretreatment procedures at acidic $\mathrm{pH}$ throughout the study. For this reason, further studies were carried out with acetone and $\mathrm{NaOH}$-activated electrodes for labelfree biosensor applications. The studies based on guanine signal measurement performed with dsDNA are shown in Figure 6. 

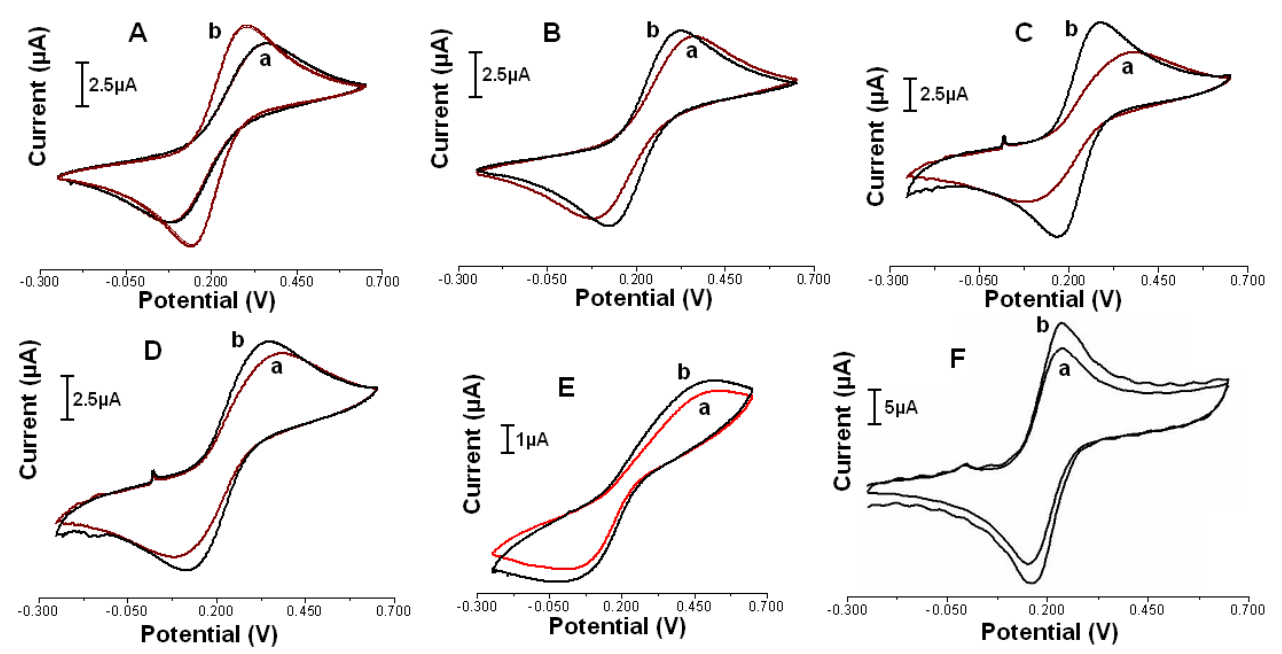

Figure 5. Voltammograms obtained from bare (a) and MWCNTs-contained (b) SPE surfaces with the solution of $10 \mathrm{mM}$ $\mathrm{K}_{4}\left[\mathrm{Fe}(\mathrm{CN})_{6}\right] / \mathrm{K}_{3}\left[\mathrm{Fe}(\mathrm{CN})_{6}\right]$ (1: 1) containing $1 \mathrm{M} \mathrm{KCl}$. The modifications of $2 \%$ ratio of bamboo(A,C, E and $\left.\mathrm{F}\right)$ or hollowstructure(B and D) MWCNTs in SPE the surface of the SPEs were pretreated with $\mathrm{H}_{2} \mathrm{SO}_{4}(\mathrm{~A}, \mathrm{~B})$, acetone (C,D), Dimethylformamide(E) or $\mathrm{NaOH}(\mathrm{F})$. CV measurement parameters as similarly with the Figure 2.

SPEs were pretreated with $\mathrm{H}_{2} \mathrm{SO}_{4}(\mathrm{~A}, \mathrm{~B})$, acetone (C,D), Dimethylformamide(E) or $\mathrm{NaOH}(\mathrm{F}) . \mathrm{CV}$ measurement parameters as similarly with the Figure 2.

In label-free DNA biosensor studies it is expected that the guanine signal increase is obtained with the nanomaterial modified electrodes. For this

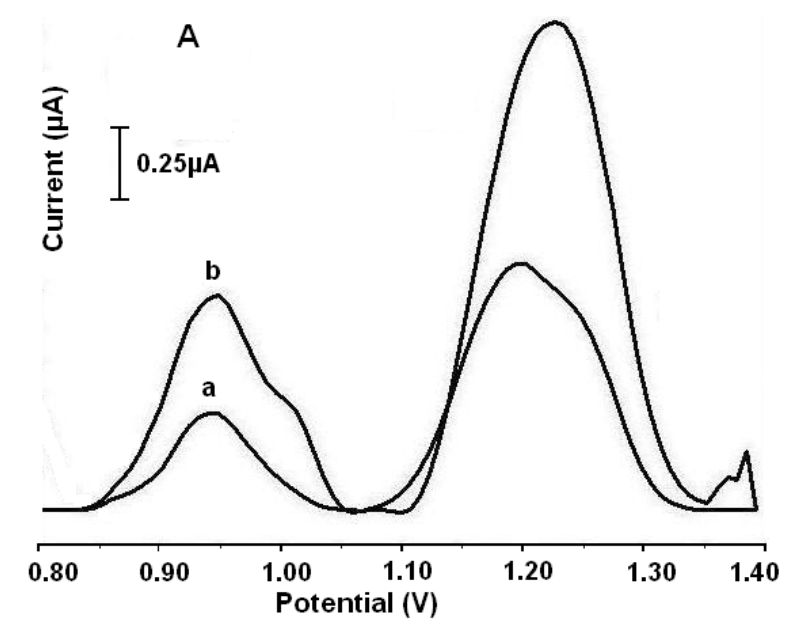

purpose, $20 \mathrm{ppm}$ dsDNA was immobilized in acetone(Figure 6A) or $\mathrm{NaOH}($ Figure $6 \mathrm{~B}$ ) activated surfaces for 1 hour. After washing, guanine and adenine signals obtained from bare SPE or bamboo-structure CNT-modified SPE measured by DPV method were examined.

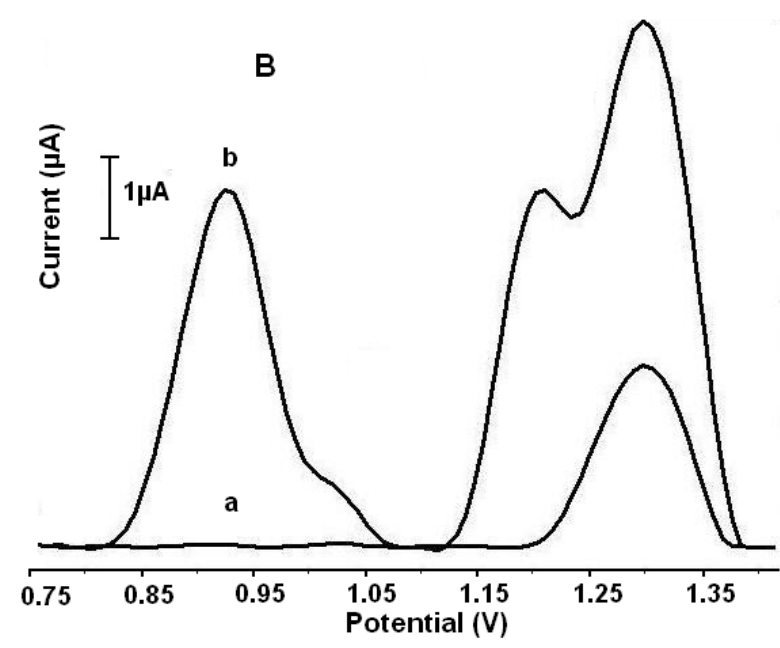

Figure 6. Influence of acetone (A) and $\mathrm{NaOH}(\mathrm{B})$-based pretreatment process on the sensitivity of biosensor by using guaninecontained double stranded DNA. DPV of guanine oxidation signals obtained from DNA-modified bare (a) and bamboostructured MWCNTs modified (b) electrodes.

The average guanine signal was observed as $332 \mathrm{nA}$ with bare electrode and $731 \mathrm{nA}$ with nanomaterial modified SPE by using acetone pretreatment method (Figure 6A). The CNT- modified electrode (Figure 6A,b) showed nearly two times increase at guanine response when compared to the bare electrode(Figure 6A,a). On the other hand, the average guanine response was 
obtained as $4.36 \mu \mathrm{A}$ with $\mathrm{NaOH}$-pretreated and CNT-contained SPE (Figure 6B,b). In comparison to the responses observed by using $20 \mu \mathrm{g} / \mathrm{mL}$ dsDNA immobilized bare electrode (Figure 6B,a), approximately 62 folds increment at the guanine peak was obtained by using DNA modified CNTincluded SPE (Figure 6B, b). This huge signal enhancement originated from bamboo-type carbon nanotubes. The results of this experiment showed that carbon nanotubes could be used successfully to reduce the detection limit in biosensor design studies. On the other hand, in adenine signals obtained at about $1.25 \mathrm{~V}$ (second peaks of Figure $6 \mathrm{~A}$ and $\mathrm{B}$ at about $1.25 \mathrm{~V}$ ), significant signal increases were obtained with nanotube modified electrodes.

If the acetone and $\mathrm{NaOH}$ pretreatment techniques are compared in terms of ferricyanide/ferrocyanide signal increase between bare and CNT-modified electrode, acetone-based method showed 3.2 times more increase (Figure 5C) than $\mathrm{NaOH}$ pretreatment technique(Figure 5F). However, when the obtained guanine signals are evaluated, the signal obtained by the $\mathrm{NaOH}$ based pretreatment is much more than the acetone based method. This demonstrates the importance of pretreatment in biosensor studies. As a result, the guanine signal obtained after DNA immobilization on the electrode should be carefully examined after a certain increase in the electron transfer rate to be observed by the activation of the nanomaterial modified electrode.

There are also numerous conditions for pretreatment of SPEs in the literature for different research purposes [23]. For example, Morrin et al applied an electrochemical pretreatment based on $\mathrm{CV}$ method scanning between $+1.2 \mathrm{~V}$ and $+1.5 \mathrm{~V}$ in $0.2 \mathrm{M} \mathrm{H}_{2} \mathrm{SO}_{4}$ solution [24]. Lee et al. also used $\mathrm{CV}$ technique scanning from $-0.5 \mathrm{~V}$ to $+0.2 \mathrm{~V}$ for $20 \mathrm{~min}$ in $0.1 \mathrm{M} \mathrm{NaNO}{ }_{3}[25$.]. In another work, screen printed carbon electrodes were activated in saturated $\mathrm{Na}_{2} \mathrm{CO}_{3}$ solution at $+1.2 \mathrm{~V}$ for $5 \mathrm{~min}$ [17]. Patris et al. pretreated SPEs for $1.5 \mathrm{~min}$ in $\mathrm{H}_{2} \mathrm{SO}_{4}$ under $+1.6 \mathrm{~V}$ potential application [26]. When we compared our simple $\mathrm{NaOH}$ pretreatment protocol with these studies, it has advantages such as shorter activation time (2 $\mathrm{min})$ and potential application $(+1.5 \mathrm{~V})$. In addition, it is the first time that $\mathrm{NaOH}$ pretreatment method and bamboo-type CNTs modification have been shown to increase the DNA signal by nearly 62 times.

\section{CONCLUSION}

The bamboo-type MWCNTs structure was modified to the SPE surface which is suitable for measuring intrinsic guanine oxidation signal directly. The main advantage of the applied protocol is its effective pretreatment step applied on CNTs-contained SPE providing highly enhanced signal with high sensitivity. The effect of bamboo-type carbon nanotubes on guanine signal enrichment was shown for the first time in this study. The modification of SPEs and its pretreatment with $\mathrm{NaOH}$ provide enhanced adsorption of DNA on the surface of the sensor, and thus they offer nearly 62 times increased sensitivity besides low detection limit when compared with CNTs-free sensor. In the new biosensor systems to be designed, if the method in this sensor based on label-free measurement is used, a new and strong alternative will be introduced to the traditional methods. Because indicator-free detection is greatly simplify the sensing methodology by eliminating the use of label and the need for the additional timeconsuming process for indicator-DNA interaction. Future plan for this laboratory will be the development of hybridization-based DNA biosensors that can be converted into microchips.

\section{Acknowledgements}

D.O.A would like to thank the Professor Marco Mascini for his valuable technical support. D.OA. also acknowledges technical support from the Pharmaceutical Sciences Research Centre (FABAL) of Ege University, Faculty of Pharmacy. 


\section{REFERENCES}

[1]. Lazerges M., Bedioui F. Analysis of the evolution of the detection limits of electrochemical DNA biosensors. Anal. Bioanal. Chem. 405 (2013) 3705-3714.

[2]. Liu Z., Tabakman S., Welsher K., Dai H.J. Carbon nanotubes in biology and medicine: In vitro and in vivo detection, imaging and drug delivery. Nano Res. 2 (2009) 85-120.

[3]. Trojanowicz M. Analytical applications of carbon nanotubes: a review. TrAC Trends Anal. Chem. 25 (2006) 480-489.

[4]. Wang J., Lin Y.H. Functionalized carbon nanotubes and nanofibers for biosensing applications. TrAC Trends Anal. Chem. 27 (2008) 619-626.

[5]. Li F., Peng J., Wang J., Tang H., Tan L., Xie Q., Yao S. Carbon nanotube-based label-free electrochemical biosensor for sensitive detection of miRNA-24. Biosens. Bioelectron. 54 (2014) 158-164.

[6]. Zhu X., Li J., He H., Huang M., Zhang X., Wang S. Application of nanomaterials in the bioanalytical detection of diseaserelated genes yayinindan Biosensors and Bioelectronics 74 (2015) 113-133.

[7]. Erdem A., Kuralay F., Cubukcu H.E., Congur G., Karadeniz H., Canavar E. Sensitive sepiolite-carbon nanotubes based disposable electrodes for direct detection of DNA and anticancer drug-DNA interactions. Analyst 137 (2012) 4001-4004.

[8]. Sengiz C., Congur G., Eksin E., Erdem A. Multiwalled Carbon Nanotubes-Chitosan Modified Single-Use Biosensors for Electrochemical Monitoring of Drug-DNA Interactions. Electroanal. 27 (2015) 1855 1863.

[9]. Zhang Q.D., Piro B., Noël V., Reisberg S., Pham M.C. Functionalization of singlewalled carbon nanotubes for direct and selective electrochemical detection of DNA. Analyst 136 (2011) 1023-1028.

[10].Lee A.C., Du D., Chen B., Heng C.K., Lim T.M., Lin, Y. Electrochemical detection of leukemia oncogenes using enzyme-loaded carbon nanotube labels. Analyst 139 (2014) 4223-4230.

[11].Thuy N.T., Tama P.D., Tuan M.A., Le A.-T., Tama L.T., Thu V.V., Hieu N.V., Chien N.D., Detection of pathogenic microorganisms using biosensor based on multi-walled carbon nanotubes dispersed in DNA solution. Curr. Appl. Phys. 12 (2012) 1553-1560.

[12].Zhang X., Jiao K., Liu S., Hu Y. Readily reusable electrochemical DNA hybridization biosensor based on the interaction of DNA with single-walled carbon nanotubes. Anal. Chem. 81 (2009) 6006-6012.

[13].Ozkan-Ariksoysal D., Kayran Y.U., Yilmaz F.F., Ciucu A.A., David I.G., David V., Hosgor-Limoncu M., Ozsoz M. DNAwrapped multi-walled carbon nanotube modified electrochemical biosensor for the detection of Escherichia coli from real samples. Talanta 166 (2017) 27-35.

[14].Chekin F., Gorton L., Tapsobea I. Direct and mediated electrochemistry of peroxidase and its electrocatalysis on a variety of screenprinted carbon electrodes: amperometric hydrogen peroxide and phenols biosensor. Anal. Bioanal. Chem. 407 (2015) 439-446.

[15].Erdem A., Karadeniz H., Canavar P.E., Congur G. Single-Use Sensor Platforms Based on Carbon Nanotubes for Electrochemical Detection of DNA Hybridization Related to Microcystis spp. Electroanal. 24 (2012) $502-511$.

[16].Jeong S.H., Kim C.S., Yang J. Comparison of the sensitivity of thiolated aptamer based biosensor according to the condition of electrode substrates. BioChip J. 4 (2010) 141-147.

[17].Cui G., Yoo J.H., Lee J.S., Yoo J., Uhm J.H., Cha G.S., Nam H. Effect of pre-treatment on the surface and electrochemical properties of screen-printed carbon paste electrodes. Analyst 126 (2001) 1399-1403.

[18].Carpini G., Lucarelli F., Marrazza G., Mascini M. Oligonucleotide-modified screen-printed gold electrodes for enzyme- 
amplified sensing of nucleic acids. Biosens. Bioelectron. 20 (2004) 167-175.

[19].Trojanowicz M., Mulcandani A., Mascini M. Carbon nanotubes-modified screen-printed electrodes for chemical sensors and biosensors. Anal. Lett.,37 (2004) 3185- 3204

[20].Wen J.G., Li W. Z., Huang Z. P., Tu Y., Wang D. Z., Chen J. H., Yang S. X., Ren Z. F. Microstructural Studies on CVD grown multiwall carbon nanotubes and their breaking behaviors by TEM., 199th meeting of The electrochemical Society, March 2530, 2001, Washington, DC.

[21].Williams K.A., Veenhuizen P.T.M. de la Torre BG., Eritja R., Dekker C. Nanotechnology: carbon nanotubes with DNA recognition. Nature, 420 (2002), 761.

[22].Lin Y., Lu F., Wang J. Disposable carbon nanotube modified screen printed biosensor for amperometric detection of organophosphorus pesticides and verve agents. Electroanal., 16 (2004) 145-149.
[23].Topkaya S.N., Ozkan-Ariksoysal D. Prostate Cancer Biomarker Detection with Carbon Nanotubes Modified Screen Printed Electrodes Electroanal. 28 (2016) 1077 1084.

[24].Morrin A., Killard A.J., Smyth M. R. Electrochemical characterization of commercial and home-made Screen-Printed Carbon electrodes. Anal. Lett. 36 (2003), 2021-2039.

[25].Lee P.T., Lowinsohn D., Compton R. G. The Use of Screen-Printed Electrodes in a Proof of Concept Electrochemical Estimation of Homocysteine and Glutathione in the Presence of Cysteine Using Catechol. Sensors 14 (2014), 10395-10411.

[26].Patris S., De Pauw P., Vandeput M., Huet J., Van Antwerpen P., Muyldermans S., Kauffmann J.M. Nanoimmunoassay onto a screen printed electrode for HER2 breast cancer biomarker determination. Talanta 130 (2014), 164-170. 